\title{
Pertumbuhan Dan Produksi Pinang (Areca caatechu L.) Pada Daerah Pasang Surut Air Laut Dan Daerah Pasang Surut Air Tawar
}

\author{
${ }^{1}$ Jessica, ${ }^{2 *}$ Yulistiati Nengsih dan ${ }^{2}$ Rudi Hartawan \\ ${ }^{1}$ Alumni Program Studi Agroteknologi, Fakultas Pertanian Universitas Batanghari \\ ${ }^{2}$ Program Studi Agroteknologi, Fakultas Pertanian Universitas Batanghari \\ Jl. Slamet Riyadi, Broni Jambi, 36122. Telp. +62741 60103 \\ 2*e-mail korespondensi : nyulistiati@yahoo.com
}

\begin{abstract}
The research of difference in growth and production of Areca fruit (Areca caatechu L.) tidal area of fFreshwater and tidal areas was to determine the differences in growth and production of tidal arecaea and freshwater tidal areas. This research was carried out in two different areas, namely freshwater tidal land in Sialang Village, Tungkal Ilir District, Tanjung Jabung Barat Regency and freshwater tidal land in Sungai Beras Village, Mendahara Ulu District, Tanjung Jabung Timur Regency from January to February 2019 using the method survey of several sample farmers. Data analysis was performed by static analysis with descriptive methods in the form of tabulations and inference methods using the $-z$ test on each parameter starting from planting distance, stem height, stem circumference, age of production start, productivity of freshwater tidal areca fruit, fruit productivity areca palm tides, water $\mathrm{pH}$, salt content, and pH of water. The z-test results in this study indicate that the influence of tide and freshwater has significant differences in the growth and productivity of areca nut. On freshwater tidal land the most productive land and produce physical data of plants are plant distance $(2.95 \mathrm{~m})$, stem height $(10.52 \mathrm{~m})$, stem circumference $(48.66 \mathrm{~m})$, age of production start (4 years), productivity (15.87 tons / ha), soil pH (4.9), salinity (0.1 ppt), and $\mathrm{pH}$ of water (4.0).
\end{abstract}

Keywords: productivity, growth, tidal land, freshwater tidal land

Abstrak. Penelitian perbedaan pertumbuhan dan produksi buah Pinang (Areca caatechu L.) daerah pasang surut air laut dan daerah pasang surut air tawar, bertujuan untuk mengetahui perbedaan pertumbuhan dan produksi buah pinang lahan pasang surut air laut dan daerah pasang surut air tawar. Penelitian ini di laksanakan didua daerah berbeda yaitu lahan pasang surut air tawar berada di Desa Sialang Kecamatan Tungkal Ilir Kabupaten Tanjung Jabung Barat dan lahan pasang surut air tawar di Desa Sungai Beras Kecamatan Mendahara Ulu Kabupaten Tanjung Jabung Timur dari bulan Januari sampai Februari tahun 2019 menggunakan metode survey dari beberapa petani sampel. Analisis data dilakukan dengan analisis statiska dengan metode deskriptif dalam bentuk tabulasi dan metode inferensi menggunakan uji $-\mathrm{z}$ pada tiap-tiap parameter mulai dari jarak tanam, tinggi batang, lingkar batang, umur mulai produksi, produktivitas buah pinang lahan pasang surut air tawar, produktivitas buah pinang lahan pasang surut air laut, $\mathrm{pH}$ tanah, kadar garam, dan $\mathrm{pH}$ air. Hasil uji - z menunjukan bahwa pengaruh air pasang surut air laut dan air tawar terdapat perbedaan nyata terhadap pertumbuhan dan produktivitas pinang. Pada lahan pasang surut air tawar menjadi lahan produktivitas terbanyak dan menghasilkan data fisik tanaman yaitu jarak tanaman $(2,95 \mathrm{~m})$, tinggi batang $(10,52 \mathrm{~m})$, lingkar batang $(48,66 \mathrm{~m})$, umur mulai produksi (4 tahun), produktivitas $(15,87$ ton/Ha), $\mathrm{pH}$ tanah $(4,9)$, kadar garam $(0,1 \mathrm{ppt})$, dan $\mathrm{pH}$ air $(4,0)$.

Kata kunci : produktivitas, pertumbuhan, lahan pasang surut air laut, lahan pasang surut air tawar

\section{PENDAHULUAN}

Tanaman pinang (Areca catechu L.) sudah dimanfaatkan sejak lama terutama daerah-daerah Asia Selatan dan Timur sampai daerah Kepulauan Pasifik. Pinang merupakan komoditi yang termasuk subsektor perkebunan yang berpotensi untuk diekspor. Tanaman pinang dapat diandalkan dan dibanggakan karena memiliki beberapa keunggulan diantaranya mudah memperoleh bibit, jarang diganggu hama penyakit, mampu memproduksi buah walaupun hanya ditanam diperkarangan, berbuah tanpa kenal musim, jarak 
tanam relatif dekat, dan biaya investasi tidak mutlak besar. Pinang juga dapat dimanfaatkan sebagai bahan baku industri farmasi.

Pinang tersebar di semua wilayah Indonesia, namun penyebaran terbesar dan sekaligus sebagai daerah pengekspor biji pinang terdapat di Pulau Sumatra antara lain di Jambi. Sementara daerah lain masih terbatas untuk konsumsi lokal. Tanaman pinang merupakan komoditas unggulan perkebunan Provinsi Jambi di samping komoditas tanaman perkebunan lain, seperti: tanaman kelapa sawit, karet, kelapa, dan kakao (Dinas Pertanian Tanaman Pangan Provinsi Jambi, 2014).

Provinsi Jambi merupakan salah satu penghasil pinang di Indonesia, di mana terdapat 10 Kabupaten/Kota yang melakukan usaha tani pinang. Kabupaten Tanjung Jabung Barat memiliki produksi pinang tertinggi yaitu 9.776 ton dengan luas tanam 8.615 Ha, dan produktivitas 1,13 ton/Ha. Kabupaten Tanjung Jabung Timur penghasil pinang terbesar kedua di Provinsi Jambi dengan produksi pinang 5.736 ton dengan luas tanam 8.846 Ha, dan produktivitas 0,64 ton per Ha (Dinas Perkebunan Provinsi Jambi, 2015).

Provinsi Jambi sebagai sentra penyebaran pinang terbesar di Indonesia, hasil eksplorasi dan identifikasi menghasilkan 5 aksesi pinang yang potensial, yaitu Betara-1,Betara 2, Muara Sabak Timur-1, Muara Sabak Timur-2, dan Muara Sabak Timur-3 (Miftahorachman, 2016).

Saat ini lahan-lahan subur untuk perkebunan semakin terbatas ketersediaannya akibat berbagai kegiatan pembangunan industri, pariwisata, perumahan, jalan, dan pemukiman, akibatnya lahan pengembangan perkebunan bergeser kelahan-lahan marginal seperti lahan pasang surut (Najiyatiet al., 2005).

Hasil penelitian Ismail et al (1993), lahan pasang surut Indonesia cukup potensial untuk usaha pertanian baik untuk tanaman pangan, perkebunan, hortikultura maupun usaha peternakan. Selanjutnya dijelaskan oleh Alihamsyah (2002) kedepan lahan rawa ini menjadi sangat strategis dan penting bagi pengembangan pertanian sekaligus mendukung ketahanan pangan dan usaha agribisnis.

Berdasarkan hasil pemetaan Pusat Data Rawa Indonesia (2018), lahan rawa di Indonesia tersebar di beberapa pulau, yaitu Sumatera, Kalimantan, Sulawesi dan Irian Jaya. Luas lahan rawa Indonesia diperkirakan mencapai 33.393.570 hektar yang terdiri dari 20.096.800 hektar $(60,2 \%)$ lahan pasang surut dan 13.296.770 hektar (39,8\%) lahan rawa non-pasang surut (lebak). Dari luasan tersebut, total lahan rawa yang dikembangkan pemerintah adalah 1.8 juta ha dan oleh masyarakat sekitar 2.4 juta ha. Kawasan itu tersebar di pantai timur dan utara pulau Sumatera, pantai barat, selatan, dan timur pulau Kalimantan, pantai barat dan timur pulau Sulawesi, serta pantai selatan pulau Papua. Dari jumlah itu sebanyak 9,53 juta ha ternyata sesuai untuk kegiatan budidaya pertanian. Saat ini luas lahan rawa yang dimanfaatkan untuk budidaya pertanian baru mencapai sekitar 2,270 juta ha, artinya lahan rawa yang dimanfaatkan untuk kegiatan pertanian hanya 23,8 persen dari luas total lahan rawa yang sesuai untuk kegiatan pertanian.

Berdasarkan pemetaan Badan Litbang Pertanian tahun 2009, lahan rawa pasang surut memiliki luas paling besar, yakni mencapai 20,1 juta ha. Lahan tersebut terdiri atas tipologi lahan potensial seluas 2,1 juta ha, sulfat masam (6,7 juta ha), gambut (10,9 juta ha), dan salin (0,4 juta ha). Sementara itu, luas lahan rawa lebak di Indonesia sekitar 13,3 juta ha, 4,2 juta ha berupa lebak dangkal, 6,1 juta ha lebak tengahan, dan 3,0 juta ha lebak dalam.

Menurut Noor (2004), rawa adalah kawasan sepanjang pantai, aliran sungai, danau, atau lebak yang menjorok masuk (intake) ke pedalaman sampai sekitar $100 \mathrm{~km}$ atau sejauh dirasakannya pengaruh gerakan pasang. Jadi, lahan rawa dapat dikatakan sebagai lahan yang mendapat pengaruh pasang surut air laut atau sungai di sekitarnya. Di Indonesia telah disepakai istilah rawa dalam dua pengertian, yakni rawa pasang surut dan rawa lebak. Rawa pasang surut diartikan sebagai daerah rawa yang mendapatkan pengaruh langsung atau tidak langsung oleh ayunan pasang surut air laut atau sungai di sekitarnya. Sedangkan rawa lebak adalah daerah rawa yang mengalami genangan selama lebih dari tiga bulan dengan tinggi genangan terendah $25-50 \mathrm{~cm}$.

Provinsi Jambi diperkirakan memiliki lahan rawa seluas 684.000 ha, berpotensi untuk pengembangan pertanian 246.481 ha terdiri dari lahan pasang surut 206.832 ha dan lahan non pasang surut (lebak) 40.521 ha (Bappeda Jambi, 2016). 
Lahan pasang surut air laut adalah lahan yang jumlah airnya dipengaruhi oleh pasang surutnya air laut (asin). Air laut mengandung residu garam yang tinggi. Garam mempengaruhi pertumbuhan tanaman melalui keracunan yang diakibatkan penyerapan unsur penyusun garam secara berlebihan seperti sodium, penurunan penyerapan air (cekaman air) dan penurunan dalam penyerapan unsur-unsur penting bagi tanaman khususnya potassium (Food and Agriculture Organization. 2008).

Wilayah pasang surut air tawar adalah wilayah rawa yang mengalir kearah hulu sungai. Wilayahnya masih termasuk daerah aliran sungai bagian bawah, namun posisinya lebih ke dalam ke arah daratan, atau ke arah hulu sungai. Di wilayah ini energi sungai, berupa gerakan aliran sungai ke arah laut, bertemu dengan energi pasang surut yang umumnya terjadi dua kali dalam sehari (semi diurnal). Karena wilayahnya sudah berada di luar pengaruh air asin/salin, yang dominan adalah pengaruh air tawar (fresh water) dari sungai sendiri (Suriadikarta dan Setyorini, 2006).

\section{METODE PENELITIAN}

Penelitian dilaksanakan pada bulan April sampai Juli 2019 pada lahan pasang surut air tawar di Desa Sungai Beras, Kecamatan Mendahara Ulu, Kabupaten Tanjung Jabung Timur dan lahan pasang surut air laut di Desa Sialang, Kecamatan Tungkal Ilir, Kabupaten Tanjung Jabung Barat.

Bahan yang digunakan dalam penelitian ini adalah pertanaman pinang yang berumur 10-15 tahun. Alat yang digunakan dalam penelitian ini meliputi GPS, meteran, timbangan, lembar kuisioner, alat perekam, pH meter, refraktometer dan kamera.

Penelitian ini menggunakan metode survey pada lahan petani yang ditanami pinang. Lokasi penelitian ini dipilih secara sengaja dimana lokasi-lokasi tersebut terdapat budidaya tanaman pinanglahan pasang surut air tawar dan pasang surut air laut.

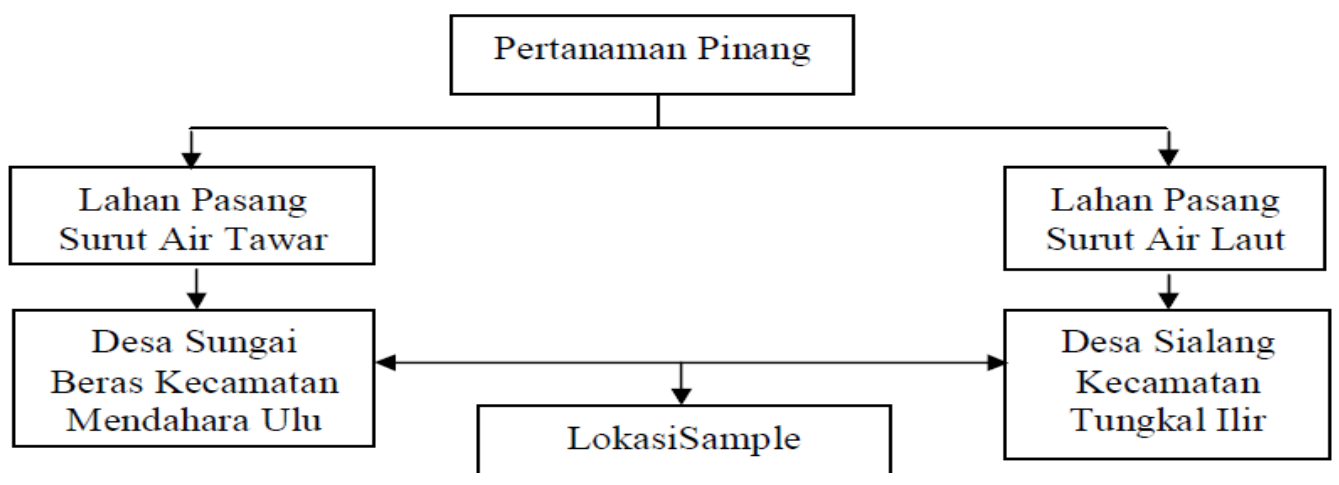

Gambar 1. Lokasi dan Petani Sample

Metode pengambilan sample menggunakan metode Systemic Sampling dan digambarkan sebagai berikut :

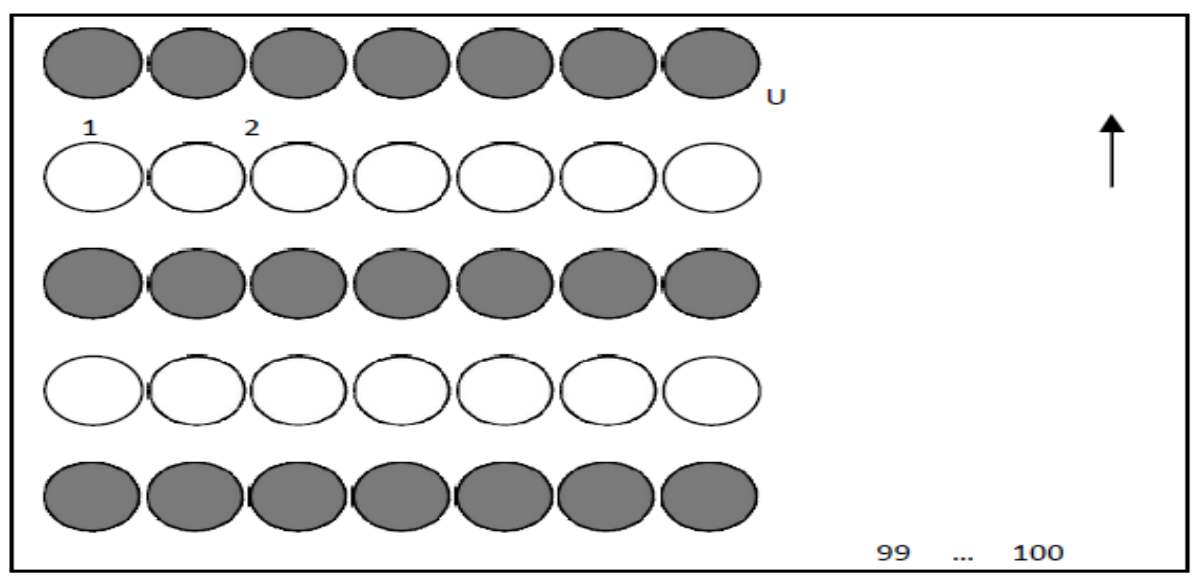

Gambar 2. Bentuk Titik - Titik Pohon Sampel Secara Sederhana 
Pada gambar diatas menunjukkan titik hitam yang mana sebagai contoh pohon sampel yang mempunyai populasi 100 pohon dan dilanjutkan dengan perhitungan nilai $\mathrm{K}:$ RumusK $=\frac{N}{n} . \quad \mathrm{K}=$ jika jumlah tanaman 100 maka sampel yang diambil adalah 15 tanaman. K = 100:15 = 6 dan dibulatkan menjadi 7. Selanjutnya menyiapkan lotre sebanyak 9 buah kartu lotre yang mana kartu tersebut telah diberi angka 1 sampai 9 dan diacak kartu yang telah diberi nomor. Bila angka pertama yang keluar adalah 6 makan mulailah pengambilan sampel pohon dari nomor 6 kemudian lakukan ulangan menghitung sebanyak 7 kali sesuai nilai $\mathrm{K}$ diatas. Contoh angka sampel : 6, 13, 20, 27 dan seterusnya sampai 15 tanaman.

Peubah yang diamati adalah 1) Jarak tanam (m). Model posisi tanaman dan jarak tanam diatur saat penelitian dengan mengukur jarak pinang dengan cara mengukur antar pokok tanaman menggunakan meteran. 2) Tinggi batang (m). Pengukuran tinggi batang dilakukan dengan menggunakan meteran. Dengan cara mengukur tinggi batang dari pangkal batang sampai ketajuk menggunakan galah / bambu. 3) Lingkar batang $(\mathrm{cm})$.Pengukuran lingkar batang dilakukan menggunakan meteran, dengan cara mengambil rata-rata lingkar batang yang diukur setengah meter dari pangkal. 4) Umur mulai produksi (tahun).Untuk mengetahui umur tanaman mulai berbuah maka dilakukan wawancara kepada petani pinang. 5) Produktivitas buah pinang lahan pasang surut air tawar (kg/Ha).Pengamatan produksi buah yang dihasilkan dilakukan dengan cara menimbang hasil buah pinang per pohon pada lahan pasang surut air tawar. 6) Produktivitas buah pinang lahan pasang surut air laut $\left(\mathrm{kg} \mathrm{Ha}^{-1}\right)$. 7)Pengamatan produksi buah yang dihasilkan dilakukan dengan cara menimbang hasil buah pinang per pohon pada lahan pasang surut air laut. 8) $\mathrm{pH}$ tanah. Untuk mengukur kemasaman tanah, dilakukan pengukuran $\mathrm{pH}$ tanah dengan menggunakan alat ukur $\mathrm{pH}$ meter yang diletakkan diatas tanah. 9) Kadar garam. Untuk mengetahui salinitas (tingkat kadar garam atau keasinan terlarut dalam air) dengan menggunakan refraktometer. 10) $\mathrm{pH}$ air. Untuk mengukur $\mathrm{pH}$ air, dilakukan pengukuran $\mathrm{pH}$ air dengan menggunakan alat ukur $\mathrm{pH}$ meter.

Guna menjawab hipotesis yang diajukan, data-data yang diperoleh dilapangan dilakukan analisis statistika dengan metode deskriptif dan bentuk tabulasi.

$$
z=\frac{x_{1}-x_{2}}{\sqrt{\frac{s_{1}^{2}}{n_{1}}+\frac{s_{2}^{2}}{n_{2}}}}
$$

Keterangan $: \mathrm{z}=$ Nilai uji statistik, $\mathrm{x}_{1}-\mathrm{x}_{2}=$ Selisihdua rata - rata hitungsampel 1 dansampel 2, $\mathrm{m}_{1}-\mathrm{m}_{2}=$ Selisih dua rata-rata hitungpopulasi 1 danpopulasi $2, \mathrm{~S}_{\mathrm{x} 1-\mathrm{x} 2}=$ Standardeviasiselisihduapopulasi

\section{HASIL DAN PEMBAHASAN}

Survey dlakukan terhadap 10 petani di Desa Sialang Kecamatan Tungkal Ilir Kabupaten Tanjung Jabung Timur dan 10 petani di Desa Sungai Beras Kecamatan Mendahara Ulu Kabupaten Tanjung Jabung Barat. Adapun titik koordinat lokasi masing-masing petani sampel dapat dilihat pada Tabel 1.

Tabel 1. Lokasi-Lokasi Sampel Petani

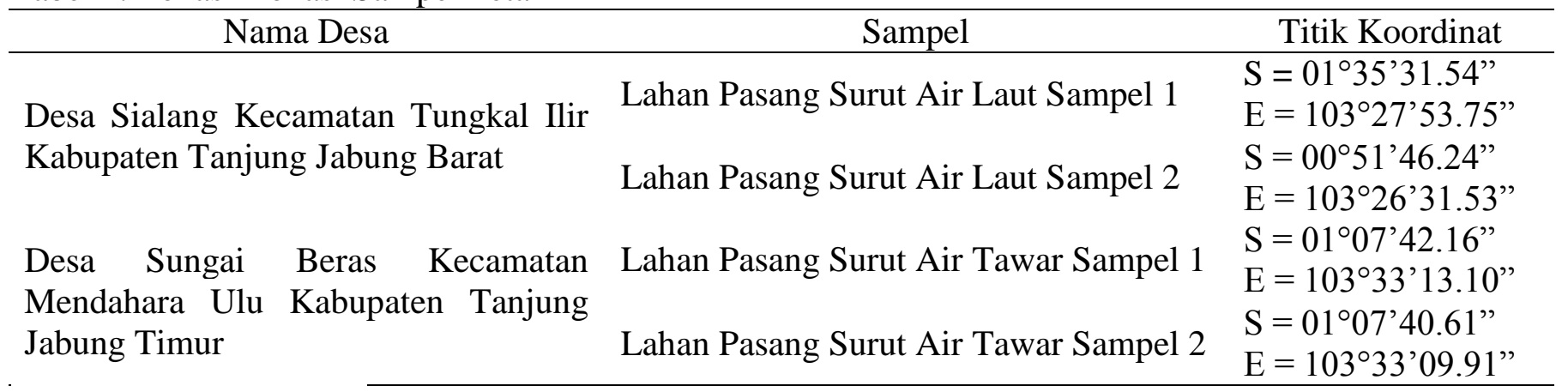

Keterangan : $\mathrm{S}=$ South

$$
\mathrm{E}=\text { East }
$$


Dari Tabel 1, dapat dilihat terdapat perbedaan titik koordinat disetiap lokasi sampel lahan. Perbedaan satu menit titik koordinat sama dengan jaraknya 30 meter. Pengamatan dilakukan pada tanaman yang ada pada daerah yang diterakan dengan koordinat. Data hasil pengamatan disajikan pada Tabel 2.

Berdasarkan hasil pengamatan, dapat diketahui jarak tanam, tinggi tanaman, lingkar batang, umur mulai produksi, produktivitas buah pinang lahan pasang surut air tawar dan produktivitas buah pinang lahan pasang surut air laut.

Tabel 2. Perbandingan nilai peubah pada ekologi lahan pasang surut air tawar dengan pasang surut air laut

\begin{tabular}{|c|c|c|c|c|c|}
\hline \multirow{2}{*}{ No. } & \multirow{2}{*}{ Peubah yang Diukur } & \multicolumn{2}{|c|}{ Ekologi Lahan } & \multirow{2}{*}{ t hit } & \multirow{2}{*}{$P$} \\
\hline & & PSAT $^{1}$ & PSAL $^{2}$ & & \\
\hline 1. & Jarak tanam $(\mathrm{cm})$ & 2,95 & 2,31 & $7,26 * *$ & 0,00 \\
\hline 2. & Tinggi tanaman (m) & 10,52 & 9,01 & $3,85^{* *}$ & 0,00 \\
\hline 3. & Lingkar batang (cm) & 48,66 & 42,96 & $3,42 * *$ & 0,01 \\
\hline 4. & Umur mulai berbuah (tahun) & 4 & 5 & $4,43 * *$ & 0,04 \\
\hline 5. & Estimasi produktivitas $\left(\mathrm{t} \mathrm{ha}^{-1} \mathrm{th}^{-1}\right)$ & 15,87 & 8,46 & $8,32 * *$ & 0,00 \\
\hline 6. & $\mathrm{pH}$ & 2,95 & 2,31 & $3,41 * *$ & 0,03 \\
\hline 7. & Kadar garam (ppt) & 10,52 & 9,01 & $4,31 * *$ & 0,04 \\
\hline
\end{tabular}

${ }^{1}$ PSAT $=$ Pasang surut air tawar

${ }^{2}$ PSAL $=$ Pasang surut air laut

** $\quad=$ Berbeda sangat nyata $(P<0,05)$

Lahan pasang surut air laut memiliki salinitas yang tinggi yang ditunjukkan pada Tabel 2 bahwa salinitas 2,1 ppt. Salinitas yang tinggi mengakibatkan menurunnya potensial air tanah dan berdampak terhadap menurunnya kemampuan menyerap air dan unsur hara bagi tanaman pinang. Kondisi ini akan mempengaruhi laju fotosintesis per satuan luas daun. Mekanisme utama penekanan laju fotosintesis terjadi karena menutupnya stomata sebagai akibat dari kemampuan tanaman dalam menyerap air berkurang. Seperti yang dinyatakan oleh Sari et al. (2006) bahwa menutupnya stomata pada daun akan memotong suplai $\mathrm{CO}_{2}$ ke sel-sel mesofil, sehingga fotosintesis terhambat dan fotosintat yang terbentuk sedikit.Sejalan dengan pendapat Basri (1991) bahwa peningkatan konsentrasi garam terlarut di dalam tanah akan meningkatkan tekanan osmotik sehingga menghambat penyerapan air dan unsur-unsur hara yang berlangsung melalui proses osmosis. Jumlah air yang masuk ke dalam akar akan berkurang sehingga mengakibatkan menipisnya jumlah persediaan air dalam tanaman.

Produktivitas buah pinang lahan pasang surut air laut lebih rendah dibandingkan dengan lahan pasang surut air tawar. Hasil uji $-\mathrm{z}$ menunjukan terdapat perbedaan yang nyata antara produktivitas lahan pasang surut air tawar dan lahan pasang surut air laut, hal ini dapat dilihat pada Tabel 1, produktivitas buah pinang lahan pasang surut air laut 8,46 ton ha $\mathrm{hahun}^{-1}$ sedangkan buah pinang lahan pasang surut air tawar 15,87 ton ha ${ }^{-1} \operatorname{tahun}^{-1}$. Hasil ini menunjukkan bahwa produktivitas buah pinang lahan pasang surut air tawar lebih besar 7,41 ton $\mathrm{ha}^{-1}$ tahun $^{-1}$ dari pada produktivitas buah pinang lahan pasang surut air laut. Hal ini diduga karena kandungan $\mathrm{Na}^{+}$yang tinggi pada lahan pasang surut air laut. Sejalan dengan pendapat Basri (1991) yang menyatakan bahwa garam-garam atau $\mathrm{Na}^{+}$yang dapat dipertukarkan akan mempengaruhi sifat-sifat tanah jika terdapat dalam keadaan yang berlebihan dalam tanah. Kelebihan unsur $\mathrm{Na}^{+}$dan $\mathrm{Cl}^{-}$dapat menekan pertumbuhan dan mengurangi produksi.

Pada lahan pasang surut air tawar pertumbuhan tanaman pinang lebih baik karena penyerapan air dan unsur hara lebih baik, hasil uji $-\mathrm{z}$ menunjukan terdapat perbedaan yang nyata jarak tanaman lahan pasang surut air tawar dan lahan pasang surut air laut sehingga tanaman pinang pada lahan air tawar jarak tanam lebih luas dibandingkan pinang lahan pasang surut air laut, hal ini dapat dilihat pada Tabel 1, bahwa jarak tanam pinang lahan pasang surut air tawar adalahh 2,95 sedangkan jarak tanam pinang lahan pasang surut air laut 2,31, ini menunjukkan jarak tanam pinang lahan pasang surut air tawar lebih lebar sebesar 0,64 $\mathrm{m}$ dibandingkan pinang lahan pasang surut air laut. 
Dilihat dari pertumbuhan tinggi dan lingkar batang tanaman pinang lahan pasang surut air tawar lebih besar dibandingkan dengan pinang lahan pasang surut air laut. Hasil uji $-\mathrm{z}$ menunjukan terdapat perbedaan yang nyata antara tinggi dan lingkar batang tanaman lahan pasang surut air tawar dan lahan pasang surut air laut. Pada Tabel 1 rata-rata tinggi tanaman pinang lahan pasang surut air tawar 10,52 $\mathrm{m}$ sedangkan tinggi tanaman pinang lahan pasang surut air laut 9,01 m. Pada Tabel 1 rata-rata lingkar batang pinang lahan pasang surut air tawar 48,66 cm sedangkan rata-rata lingkar batang lahan pasang sut air laut $42,96 \mathrm{~cm}$, hal ini menunjukan bahwa rata-rata lingkar batang pinang lahan pasang surut air tawar lebih besar 5,7 cm dibandingkan dengan rata-rata pinang lahan pasang surut air laut. Hal ini diduga karena adanya pengaruh air garam (salinitas) yang dapat menekan pertumbuhan tinggi tanaman. Sesuai dengan pendapat Basri (1991) kadar $\mathrm{Na}^{+}$membuat tanaman pinang lahan pasang surut air laut mengalami pembengkakan dan penutupan pori-pori yang diakibatkan oleh $\mathrm{Na}^{+}$yang memperburuk pertukaran gas, serta dispersi material koloid tanah yang membuat tanaman terganggu pertumbuhannya.

Nilai $\mathrm{pH}$ tanah dan $\mathrm{pH}$ air pada lahan pasang surut air laut cenderung lebih rendah dari pada $\mathrm{pH}$ tanah dan $\mathrm{pH}$ air lahan pasang surut air tawar. Sejalan dengan pendapat Aliamsyah (2004) bahwa masalah utama yang dihadapi dalam pengembangan lahan pasang surut adalah kemasaman tanah tinggi. Hal ini dapat diatasi dengan pemberian kapur atau arang sekam.

Dari hasil wawancara di lapangan terdapat perbedaan umur mulai produksi antar tanaman pinang lahan pasang surut air tawar dan lahan pasang surut air laut. Pinang lahan pasang surut air tawar mulai berproduksi pada umur 4 tahun, sedangkan pinang lahan pasang surut air laut mulai berproduksi pada umur 5 tahun, hal ini menunjukkan tanaman pinang lahan pasang surut air laut lebih lambat dalam berproduksi .

Hasil wawancara dilapangan diperoleh bahwa masyarakat petani yang melakukan pertanaman pinang di lahan pasang surut air tawar dan lahan pasang surut air laut menggunakan bibit sapuan, sama-sama melakukan pertanaman secara acak. Untuk tindakan agronomi yang dilakukan petani ini sama sekali tidak melakukan pemupukan, dan hanya melakukan penyiangan gulma secara manual.

\section{KESIMPULAN DAN SARAN}

Pertumbuhan tanaman pinang di lahan pasang surut air tawar lebih baik dibandingkan pertumbuhan di lahan pasang surut air laut. Selisih produktivitas pinang di lahan pasang surut air tawar sebesar 7,41 ton $\mathrm{ha}^{-1}$ tahun $^{-1}$ dibandingkan produktivitas di lahan pasang surut air laut.

\section{DAFTAR PUSTAKA}

Pusat Data Rawa. 2019. Pusat Data dan Informasi Rawa dan Pesisir. http://www.pusdatarawa.or.id/tentang-pusat-data-rawa/ (diakses 1 Maret 2019)

Alihamsyah, T. 2002. Potensi dan Pendayagunaan Lahan Rawa untuk Peningkatan Produksi Padi. Ekonomi Padi dan beras Indonesia. Dalam Faisal Kasrino, Effendi Pasandaran dan A.M. Fagi (Penyunting). Badan Litbang Pertanian, Jakarta.

Badan Perencanaan Daerah (Bappeda) Provinsi Jambi, 2016. Melihat Potensi Lahan Rawa Di Provinsi Jambi. (online) Jambi. Litbang . pertanian . go .id / eng /index.php /berita/4-info-aktual/164melihat-potensi-lahan-rawa-di-provinsi-jambi

Basri, H., 1991. Pengaruh Stres Garam Terhadap Pertumbuhan dan Produksi Empat Varietas Kedelai. Thesis Program Pascasarjana IPB, Bogor

Dinas Perkebunan Provinsi Jambi, 2015. Statistik Perkebunan Provinsi Jambi. Jambi.

Dinas Pertanian Tanaman Pangan Provinsi Jambi, 2014. Profil Usaha Tani di Provinsi Jambi

Ismail, I.G., T. Alihamsyah, I.P. Widjaja-Adhi, Suwarno, T. Herawati, R. Tahir dan D.E. Sianturi. 2003. Sewindu Penelitian Pertanian Lahan Rawa; Konstribusi dan Prospek Pengembangan. Pusat penelitian dan pengembangan Tanaman Pangan. Bogor.

Miftahorachman, 2016. Balai Penelitian Kelapa dan Palma Lain (Balitka). Balit Palma Manado. Manado.

Sari, H.C., S. Darmanti, dan E.D. Hastuti. 2006. Pertumbuhan tanaman jahe emprit (Zingiber officinale Var. Rubrum) pada media tanam pasir dengan salinitas yang berbeda. Buletin Anatomi dan Fisiologi $14(2)$ 
Suriadikarta, D.A. dan D. Setyorini. 2006. Teknologi pengelolaan lahan sulfat masam. hlm. 117-150. Dalam D.A. Suriadikarta, U. Kurnia, Mamat H.S., W. Hartatik, dan D. Setyorini (Ed.). Karakteristik dan Pengelolaan Lahan Rawa. Balai Besar Penelitian dan Pengembangan Sumberdaya Lahan Pertanian, Bogor.

Sihombing, T. 2000. Pinang, Budidaya dan Prospek Bisnis. Penebar Swadaya. Jakarta

Widjaja-Adhi, I.P.G. dan T. Alihamsyah. 1998. Pengembangan lahan pasang surut: potensi, prospek, dan kendala serta teknologi pengelolaannya untuk pertanian. Prosiding Seminar Nasional dan Pertemuan Tahunan HITI, 16-17 Desember 1998 